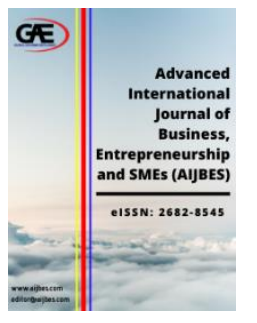

\author{
ADVANCED INTERNATIONAL JOURNAL OF \\ BUSINESS, ENTREPRENEURSHIP AND SMES \\ (AIJBES) \\ www.aijbes.com
}

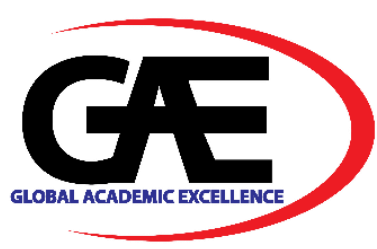

\title{
THE PERCEIVED VALUES OF INDONESIAN GENERATION Z TOWARDS A LOCAL BRAND'S PRICING STRATEGY
}

\author{
Aurelia Agatha $^{1 *}$, Kurnia Fajar Afgani ${ }^{2}$
}

1 School of Business and Management, Institut Teknologi Bandung, Indonesia

Email: aurelia_agatha@sbm-itb.ac.id

2 School of Business and Management, Institut Teknologi Bandung, Indonesia

Email: kurnia.fajar@sbm-itb.ac.id

* $\quad$ Corresponding Author

\section{Article Info:}

\section{Article history:}

Received date: 27.06 .2021

Revised date: 13.07 .2021

Accepted date: 26.07 .2021

Published date: 01.09.2021

\section{To cite this document:}

Agatha, A., \& Afgani, K. F. (2021). The Perceived Values of Indonesian Generation $\mathrm{Z}$ in Indonesia towards a Local Brand: ILKA's Pricing Strategy. Advanced International Journal of Business, Entrepreneurship and SMEs, 3 (9), 36-46.

DOI: $10.35631 /$ AIJBES.39004.

This work is licensed under CC BY 4.0

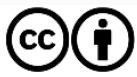

\begin{abstract}
:
The pricing strategy of a newly established business or local brand in Indonesia becomes very important. Indonesia is still believed as a developing country which the society still prefers global brands and products more than their own locals. But in these present days, people are beginning to give the locals chances and started to be proud to wear local products. The problem is that local brands are either set their prices too high because they have the overconfidence to sustain in the market or set their prices too low because they are afraid that society cannot accept them in competition with global brands. The study is researching what are the perceived values of the customers so that the right pricing strategy can be made and suit the market exactly. By using descriptive and multiple linear regression analysis, functional, economic, emotional, social, and service dimensions are taken as the variables towards the perceived values that will determine the pricing strategy of local brands, as the subject of this research. Giving questionnaires to 400 generation $\mathrm{Z}$ as the sample, those who are born between 1995 to 2010 . The result shows that the five dimensions of value are significant towards their willingness to pay more and having a linear relationship to increase the price as they increase their product's perceived values.
\end{abstract}

Keywords:

Pricing Strategy; Perceived Values; Generation Z; Local Brands; Willingness To Par

\section{Introduction}

Indonesia has still been known as a developing country in which the people themselves look up to other more developed or well-known improved countries more than their own, including 
Volume 3 Issue 9 (September 2021) PP. 36-46 DOI 10.35631/AIJBES.39004

how people are motivated to consume global brands rather than their own locals. This unfortunate phenomenon was caused by the customers' understanding that global brands have higher qualities and represent status symbolism, quality and prestige, especially western's products (Ratriyana, 2018). In Indonesia, there are two types of halo effect that can emerge which a brand cannot be separated from their home country regardless of the customers' brand knowledge; the brand image based on the country of origin (COO)'s stereotypes when the customers are lack of brand's information, and inter-trait halo effect where customers' knowledge about a particular brand might influence their judgement towards other brands that are coming from the same COO (Sulhaini, Rinuastuti and Sakti, 2019).

However, as individuals with different personalities, people's preferences and perceptions towards a product also differ from one to another. These differences are caused by the opinions toward the product's quality, price and the combination of what quality the customers can get from purchasing a product at a certain level of price (Kussudyarsana, 2016).

Indonesia's government has been trying to increase and develop the local businesses in order to bring positive impacts also for the national overall economy. As Joko Widodo, Indonesia's current president, declared that the citizens should be depending on local products consumption to improve macro economy. To support the movement, there have been inclining supports for local products, including campaigns and persuasions from influencers.

But in order to achieve it, mutual relationship between the customers and the sellers is required. To gain the customers' trust and interest, the sellers or business owners should be able to offer the right value for the targeted customers. As mentioned before, each individuals have different perceptions that reflected in their perceived values towards a products. Therefore, the sellers must know what are the perceived values of their target customers towards their offered products. The local brands have problems that are observed to be critical since they overprice or under-price their products because they are either too confident so that they set higher prices but it results in customers' avoidance that they rather spend their money on more well-known brands, or the opposite, they are lack of confidence and set their prices too low and results in customers' perception of "low price means low quality".

As the scope of limitations, the research will be conducted by giving questionnaires to generation $\mathrm{Z}$ in Indonesia, both males and females. The questionnaires aim to get the information about their perceived values for local products.

To conclude, the aim of the research is to know how are the perceived values of Indonesian generation $\mathrm{Z}$, measured by the four plus one dimensions of value, which are functional, emotional, social, economic plus service dimensions towards customers' willingness to pay higher prices on a product.

\section{Literature Review}

There are five topics that are discussed in this paper, they are local brands, perceived values, willingness to pay, generation $\mathrm{Z}$ and pricing strategies.

\section{Brand}

A name, design, symbol, or any form of major feature that can make those who see it identify a product or services from a business or organization is called brand. Brand can represent both of the product and the organization itself and provides a lot of information, such as the identity, 
value, and other unique features of themselves and also able to urge and convince the customers to make the purchase of the product or service that the organization offers, and therefore it is one of the most powerful tools to use to differentiate an organization or business than the others. To improve a brand, brand name is very important to be considered. The brand name communicates the identity of one brand from another. And therefore, a brand has its own personality which is one of a kind setting of brand affiliations inferring a guarantee to the customers, and incorporates the focal, ageless embodiment, or the centre character (Selase $e t$ al., 2018).

\section{Local Brands}

Local brands are defined as brands that exist in one country or in a limited geographical area, and international brands are the brands that have globalized marketing mix or strategy. In a short way, a brand of a global that has globalized has the opportunity to take advantage from strong economies of scale. But even though the benefit of the international brands and firms are huge and inevitable, the local brands also have strategic advantages that should be considered, such as the ability to respond to local needs, flexibility in running the business, possibility to respond to both local and international competitors and possibility to balance the portfolio of local and international brand to manage risk on worldwide basis (Schuiling and Kapferer, 2004).

However, no matter how beneficial the local brands can be, the halo effect of the foreign brands is still unable to be avoided. A country image has been often suggested as one of the factors to affect the consumers' behavior which adds up to how the consumers see the brands and products. The country of origin (COO) information takes role as a cognitive cue for the customers to generalize the attributes of the products/brands form particular countries. Especially in Indonesia, an even well-known and strong brand cannot be separated from their home country and therefore the halo effect can emerge regardless of the customers' brand knowledge (Sulhaini, Rinuastuti and Sakti, 2019).

\section{Perceived Values}

Previous studies have been conducted to determine the factors on perceived values, for example, a study by Zeithaml in 1988 which viewed value as a trade-off between getting (benefit) and giving (cost) (Zeithaml, 1988). Sweeney and Soutar then came up with the four value dimensions; functional, economy, emotional and social dimensions of values (Sweeney and Soutar, 2001) that has been proven to be successful to measure customers' perceived values of different products such as clothing and durable goods by later study by Nguyen in 2015 (Nguyen et al., 2015).

In 2018, research done by Yan Hong to determine the framework of consumer's perceived values experimented using product, cost, service and relationship dimensions. The use of the service dimension in determining perceived values also been done in 2005 by Ye and Jia and in 2015 by M Hazura, which mentioned tangibility, responsiveness and information quality as part of service.

In online platforms, the customers cannot really see the real product or feel the materials in person. This sometimes results in doubts whether to purchase the product or not because the fear of buying the wrong product or not meeting their expectations of how the products will be like. Therefore, logically, online sellers should be able to describe their offers very well and provide the demonstration of the product as best as they can so that the customers can imagine 
Volume 3 Issue 9 (September 2021) PP. 36-46 DOI 10.35631/AIJBES.39004

the real product with minimum doubts. It is very common that the customers will ask the sellers bunch of questions about the things they are interested to buy. And it is very necessary for the sellers to be able to answer and provide what the customers need to know. Despite of the information, the service given by the sellers such as their responsiveness becomes mandatory for online sellers.

\section{Functional Dimension of Value}

Functional value which includes the performance and quality of a product, is an utility derived from the customers' perceived quality and expected performance of the product. It speaks about the quality for the consistency of quality, well made products, standards acceptance, reliability and durability of the products. Quality is directly related to the customer's purchase intention and their personal attitude towards the brand. Not only that, the functional value of a product which includes the features and materials that engineered and designed specifically for the brand is to deliver a predefined performance and functionality to the consumers. Sometimes the customers expect over and above its normal functions. A product with added values and functions may be made by high quality materials to perform the customers' expectation on the product. Especially for apparels products, customers in universal are demanding desired functional and aesthetic properties in one product. The products with those added functional attributes will be sustainable to capture new market and new customers. Logically, regarding the various choices that the customers have to buy a certain product, only the best quality product will be chosen and be continuously exist and survive in the market (Zahid, 2017)

\section{Economic Dimension of Value}

The economic value or the price or value for money spent is the utility derived from the product according to its perceived short and long term costs reduction. Values of economy in the perspectives of the customers are about how a product or service is reasonably priced, offers value for money, good price for the product or service received, and would be economical compared to the other similar products or services (Nguyen et al., 2015).

Speaking of an ideal economic exchange, both the buyer and the seller refer a value that is greater than what they gave up. This means that both parties are gaining economic advantages because they each accept something that may be more useful to them compared to what has been paid. Sweeney and Soutar gave their thoughts that despite of many disagreements, economic-cognitive view of value became popular among the others even many criticized that the view is too simple and narrow. In particular, value conceptualization as quality and price trade-off was reduced to "value for money" notion (Sánchez-Fernández and Iniesta-Bonillo, 2009).

\section{Emotional Dimension of Value}

Based on Sweeney and Soutar's explanation, the utility that was derived from the feelings or states of affection that generated by a product is the emotional factor that affects the customer perceived values. The factor includes the enjoyment, relaxation, pleasure gotten by using the product and making the consumer desires to use the product again in the future.

Emotional value is an advantage gotten from experiencing something new or different which has positive impact towards consumers' purchase intention. Consumer perception about foreign and local brand also builds affective components that include consumers' emotional value that creates fun and enjoyable experiences. A previous study done by Nor Asshidin found that emotional factor is a good predictor in knowing the relationship of purchase intention 
among the consumers, or in other words, brands that offers high emotional value are likely to be purchased more (Asshidin, Abidin and Borhan, 2016).

\section{Social Dimension of Value}

The social self-concept enhancement that consists in the social value is the utility derived from the ability of enhancing social self-concept or one's image of a product. The factor is driven from how the products are able to help the users or consumers to feel more acceptable, improve their social perceptions and impression, and give them social approval (Sweeney and Soutar, 2001). This social value is important towards the customers' final decision and therefore becomes necessary for business to maintain a good social reputation (Budrevičiūtè et al., 2019). Community and sociality started to become a sensational discussion topic. Due to numerous changes in technology, politic, culture and demography, individuals in the modern society are being more detached from the past bonds and obligations with constraints but also with enduring social ties. Therefore, we can conclude that people nowadays seek products and services that can fulfill their desire for communities as social solidarity more than their use value (Jiao et al., 2018).

To conclude, this research is using four plus one (4+1) dimensions of value to determine the perceived values of generation $\mathrm{Z}$ in Indonesia. They are the four values by Sweeney and Soutar which are the functional, economic, emotional and social dimension and also service dimension. The reason that the research added service dimension is because the target subject of the research is an online store in Instagram without having any offline stores, therefore service value suits the type of the business as explained before.

\section{Willingness to Pay}

Willingness to pay a higher prices becomes one of the important goal of companies, since it is a challenge for them. More desired or expected benefits to cover the costs will result in higher retail prices. It possess great importance for the companies to have the ability to set their prices higher or in other words, charge the customers with premium prices. (Žemguliené, 2014). Previous researches have been stating that the customers' purchase intention or willingness to pay is based on their perceived values towards a product with linear relationship which means that customer's willingness to pay more for higher price or even resulted in repurchase intention and loyalty will be obtained by the perception of the customers that they are getting higher and greater perceived values (Netemeyer et al., 2004).

The tendency of the customers to be willing to pay more are also influenced by the value perception related factors. The relationship between perceived values and customers' satisfaction is backed up by the customers' experience of waiting to receive advantages that are greater than the cost they made on each purchase. A decrease or increase in cost of benefit that the customers get post-purchase changes their perceived values that leads to decreased or increased satisfaction. In short, the customer's satisfaction after purchase depends on the customers' level of perceived values that shows the relationship of importance of perceived value dimension on willingness to pay more, mediated by the customer's satisfaction (Demirgüneş, 2015).

Perceived value that has been related with the received benefits from a product is most likely related also to the sacrifices or costs that the customers made for the product, whether it is good or service. Therefore, the value will increase as the quality increases and/or the sacrifices made decreases. Those benefits are the expected benefits that mentioned in the term, that the 
Volume 3 Issue 9 (September 2021) PP. 36-46

DOI 10.35631/AIJBES.39004

customers expect from a product. These expected benefits are considered as the main determinants for a product's value that has direct effect towards customer's willingness to pay higher prices. On the other hand, the exchange of value, represented by willingness to pay and price, was considered as one of the most important practical measure of information value (Lopes and Galletta, 2006).

\section{Generation Z}

Generation $\mathrm{Z}$ is the generation born after the generation $\mathrm{Y}$, which ranged based on their born year. Oblinger and Oblinger stated that generation $\mathrm{Z}$ is the generation that was born between 1995 to 2010 (Oblinger and Oblinger, 2005). In digitization point of view, generation Z should be highlighted as those who were born in the 1990's and raised in the 2000's (Dangmei and Singh, 2016). It is the youngest generation which has their own opinions and characteristics, regardless that every human is an individual and different from one another and many attempts of generalizing a group of people have been made.

There are some opinions towards the generation including that the generation is going to spend their youth and adult in an era of the renewal of economy and social and highlighted the fact that generation $\mathrm{Z}$ can work in both real and virtual worlds as they apprehend those worlds are complementary to each other. This resulted in how generation $\mathrm{Z}$ would not only uses the internet or any sort of the world technologies, but also create and control it. They wanted to have a career immediately without any effort and look for a job around the world because they have the ability of mobility and language (Dolot, 2018).

\section{Pricing Strategy}

Price, as the only revenue generating marketing mix variable, is a strategic variable and pricing decisions may bring significant leverage to achieve the organizational success tactically and short-term oriented. The price can retaliate against and disciplines competitors by lowering it while increasing the price shows prestige or exclusivity. Therefore, a price should be managed right according to the real goals by setting the right pricing strategy.

Pricing strategy is a plan that an organization set to manage prices so that they can compete in a market and achieve the organization's goals and objectives (Weber, 2012). Setting the pricing strategy is influenced by some factors, such as the brand image, geography, discounts, price discrimination and sensitivity and other factors related. Also, each of any organization that about to set a pricing strategy should consider their shareholders too (Sammut-bonnici, 2017). There are many theories regarding the pricing strategy. But based on the Sammut-Bonnici paper as the background theory for this section, there are six (6) types of pricing strategy that can be applied. It depends on how the customers are demanding the product, how the competitor sets their prices and what are the options available. Those six types of pricing strategies are mark up pricing, value based pricing, competition based pricing, penetration pricing and skimming pricing.

\section{Methodology}

First of all, the researcher set the topic of Perceived Values towards ILKA's Pricing Strategy as the subject that represents Indonesian local brands and products. Once the topic was assured, the researcher identified the problems within the topic and done a preliminary study about ILKA and previous researches about perceived values. After setting the research framework based on the most suitable variables, a questionnaire was made in order to get real responses to answer the research objectives. The questionnaire's title is "Generation Z's Preferences in 
Volume 3 Issue 9 (September 2021) PP. 36-46 DOI 10.35631/AIJBES.39004

Shopping", conducted in Bahasa Indonesia to minimize the misunderstanding by the respondents. The questionnaire included the introduction and brief explanation of the research and the purpose and terms of the survey. It was conducted with seven parts. The first part is to collect the respondents' data, the second until the fifth part are based on the previous research regarding the functional, economic, emotional and social factors done by Sweeney and Soutar. Each of the questions were labelled as shown in table 1. Other than these questions or statements, the questionnaire also consists open questions regarding the respondents' suggestions for ILKA's specific pricing and improvements that can be done by ILKA and any other local brands in general.

Table 1: Questions Labels

\begin{tabular}{|c|c|c|}
\hline Part & Labels & Questions / Statements \\
\hline $\begin{array}{l}\text { Part II - } \\
\text { Functional } \\
\text { Dimension }\end{array}$ & $\begin{array}{l}\text { FUN2 } \\
\text { FUN3 } \\
\text { FUN4 } \\
\text { FUN5 } \\
\text { FUN6 } \\
\text { FUN7 } \\
\text { FUN8 }\end{array}$ & $\begin{array}{l}\text { "The product that I buy should be made of materials with } \\
\text { best qualities" } \\
\text { "The product that I buy should last long (high durability, } \\
\text { does not break quickly)" } \\
\text { "The product that I buy should pass the safety standards that } \\
\text { apply" } \\
\text { "The product that I buy should have good quality" } \\
\text { "The product that I buy should be able to maintain the } \\
\text { quality with consistency" } \\
\text { "The product that I buy should look good" } \\
\text { "The product that I buy should pass the quality standards } \\
\text { that apply" }\end{array}$ \\
\hline $\begin{array}{l}\text { Part III - } \\
\text { Economic } \\
\text { Dimension }\end{array}$ & $\begin{array}{l}\mathrm{ECO} 2 \\
\mathrm{ECO} 3\end{array}$ & $\begin{array}{l}\text { "The product that I buy should have a reasonable price" } \\
\text { "The product that I buy should have a suitable value } \\
\text { compared to the money spent on purchase" } \\
\text { "The product that I buy should be more economical } \\
\text { compared to the other similar products" }\end{array}$ \\
\hline $\begin{array}{l}\text { Part IV - } \\
\text { Emotional } \\
\text { Dimension }\end{array}$ & $\begin{array}{l}\text { EMO2 } \\
\text { EMO3 }\end{array}$ & $\begin{array}{l}\text { "The product that I buy should be able to make me feel good } \\
\text { (happy) after I buy it" } \\
\text { "The product that I buy should be able to make me want to } \\
\text { buy it again in the future" }\end{array}$ \\
\hline $\begin{array}{l}\text { Part V - } \\
\text { Social } \\
\text { Dimension }\end{array}$ & $\begin{array}{l}\text { SOC3 } \\
\text { SOC4 }\end{array}$ & $\begin{array}{l}\text { "The product that I buy should be able to make me feel } \\
\text { acceptable in my surroundings" } \\
\text { "The product that I buy should be able to give me good } \\
\text { impression in front of my friends and relatives" } \\
\text { "The product that I buy should suit the culture in my place" }\end{array}$ \\
\hline $\begin{array}{l}\text { Part VI - } \\
\text { Service } \\
\text { Dimension }\end{array}$ & $\begin{array}{l}\text { SER2 } \\
\text { SER3 } \\
\text { SER4 }\end{array}$ & $\begin{array}{l}\text { "I become more eager to buy a product when I receive useful } \\
\text { information" } \\
\text { "I become more eager to buy a product if the seller is } \\
\text { responsive" } \\
\text { "I become more eager to buy a product if the platform is } \\
\text { easy to use" }\end{array}$ \\
\hline $\begin{array}{l}\text { Part VII - } \\
\text { National } \\
\text { Identity }\end{array}$ & $\begin{array}{l}\mathrm{COO} 1 \\
\mathrm{COO} 2\end{array}$ & $\begin{array}{l}\text { "The brand's country of origin (national identity) matters a } \\
\text { lot for me in purchasing a product" } \\
\text { "I don't trust or want to buy Indonesia's local products" }\end{array}$ \\
\hline
\end{tabular}


Volume 3 Issue 9 (September 2021) PP. 36-46 DOI 10.35631/AIJBES.39004

\begin{tabular}{c|c|l}
\hline COO3 & $\begin{array}{l}\text { "Indonesia's local products are still unable to compete with } \\
\text { the global brands" }\end{array}$ \\
\hline $\begin{array}{c}\text { Part VIII - } \\
\text { Insights }\end{array}$ & PRICE & $\begin{array}{l}\text { "How much price do you willing to pay for the product } \\
\text { IMown above?" } \\
\text { "What are your suggestions for ILKA to improve their } \\
\text { businesses?" }\end{array}$ \\
IMPGL & "What do you think local brands in general can improve?" \\
\hline
\end{tabular}

The first step of the research analysis is to get 400 Indonesian generation Z, based on Slovin's formula of sampling, as the respondents to fill a questionnaire as the primary source of the research. The questionnaire consists of statements that should be rated from the scale of 1 (totally disagree) to 4 (totally agree) as their level of agreement towards the statement. After the target number of respondents were achieved, the data was analysed quantitatively, with the help of R Studio, an open-source application to process data (RStudio Team, 2020). The data will then be tested for its validity and reliability. The validity test was done by conducting correlation test and set the limit Speaman's correlation value of 0.5. The data's correlation value should not be above 0.5 , except for the same dimension's variables. The reliability test was done by calculating the Cronbach's alpha, setting 0.7 as the minimum of the alpha to determine whether the data is reliable or not.

To support the research, journals and papers are read and made as the secondary source of the research. Collecting secondary sources were done while getting the primary source which is the questionnaire's respondents. The data gotten from the respondents are analysed descriptively and also used multiple linear regression to get the final outcome.

\section{Discussion and Analysis}

\section{4+1 Dimensions of Value towards Customer's Willingness to Pay More}

Based on the results, this study concludes that the four plus one $(4+1)$ dimensions of value theory is applicable to the research. The descriptive analysis that was done to search for the significance order of variables found that the most important or significant variable of Indonesian generation Z's perceived values is the value for money variable, from the economic dimension of value. The entire findings of the descriptive analysis are shown in Table 2.

Table 2: Descriptive Analysis

\begin{tabular}{|c|c|c|c|c|c|c|c|}
\hline \multicolumn{2}{|c|}{$\begin{array}{c}\text { Independent } \\
\text { Variables } \\
\end{array}$} & \multirow{2}{*}{\begin{tabular}{|c|} 
Average \\
3.284 \\
\end{tabular}} & \multirow{2}{*}{\begin{tabular}{|c|}
$\begin{array}{c}\text { Scale of 3- } \\
\mathbf{4}(\boldsymbol{\%})\end{array}$ \\
$89.60 \%$ \\
\end{tabular}} & \multicolumn{2}{|c|}{$\begin{array}{c}\text { Independent } \\
\text { Variables } \\
\end{array}$} & Average & \multirow{2}{*}{$\begin{array}{c}\text { Scale of 3- } \\
\mathbf{4}(\boldsymbol{\%}) \\
95.20 \%\end{array}$} \\
\hline \multirow{8}{*}{$\begin{array}{l}\text { Functional } \\
\text { Dimension }\end{array}$} & FUN2 & & & \multirow{3}{*}{$\begin{array}{l}\text { Economic } \\
\text { Dimension }\end{array}$} & ECO2 & 3.626 & \\
\hline & FUN3 & 3.633 & $97.30 \%$ & & ECO3 & 3.667 & $97.90 \%$ \\
\hline & FUN4 & 3.521 & $89.90 \%$ & & ECO4 & 3.337 & $85.70 \%$ \\
\hline & FUN5 & 2.592 & $95.90 \%$ & \multirow{3}{*}{$\begin{array}{c}\text { Social } \\
\text { Dimension }\end{array}$} & SOC2 & 2.562 & $56.10 \%$ \\
\hline & FUN6 & 2.562 & $94.10 \%$ & & SOC3 & 2.802 & $67.40 \%$ \\
\hline & FUN7 & 3.335 & $87.50 \%$ & & SOC4 & 2.694 & $60.80 \%$ \\
\hline & FUN8 & 3.523 & $89.90 \%$ & \multirow{2}{*}{$\begin{array}{c}\text { Service } \\
\text { Dimension }\end{array}$} & SER2 & 3.626 & $96.90 \%$ \\
\hline & EMO2 & 3.408 & $91.10 \%$ & & SER2 & 3.567 & $94.40 \%$ \\
\hline
\end{tabular}


The scale 3 to 4 represents the scale of agreement. The data were further processed by using the multiple linear regression (MLR) analysis. The MLR is conducted to find the equation and significance of each dimension of value towards willingness to pay. The final result of the entire analysis is an equation to represent the contribution of each value dimension towards' generation Z's willingness to pay for a product. Before conducting the MLR, classical assumptions were checked, such as the normality test, multicollinearity test and heteroscedasticity test. All three assumptions were passed and therefore the data is normally distributed, no collinearity detected by the variance inflation factor (VIF) method, and there are no heteroscedasticity detected by using Breusch-Pagan test. The equation is shown below.

$$
\begin{gathered}
\text { Price }=-162.52+16.47 F U N+15.86 E C O+16.54 E M O+15.90 S O C \\
+17.54 S E R
\end{gathered}
$$

The equation is in thousand rupiahs. The equation can be interpreted as the price value is 162.52 when there are no value from each dimension of perceived values. The price will increase by 16.47 if functional dimension increased by 1 unit, 15.86 for economic dimension, 16.54 for emotional dimension, 15.90 for social dimension and 17.54 for service dimension.

All of the dimension of value have the same p-value of $<2 \mathrm{e}-16$ that means that they are all below 0.05 and therefore, they are all equally significant towards price. However, an increase in service dimension will have the highest contribution towards the increase of price, followed by functional, emotional, social and economic dimension respectively.

Previous studies done by Soutar and Sweeney used four dimensions of value, which are functional, economic, emotional and social values. This research tested the ability of the model to explain customer's willingness to pay measured by those four values only, the result of Rsquared is 0.8541 , which means that $85.41 \%$ of price or willingness to pay more on a product can be explained by the four dimensions of value model. But by adding service value into the model, the R-squared was improved by $7.15 \%$ that the $4+1$ dimension of value, may explain $92.56 \%$ of product's price or customer's willingness to pay and they are all significant. Therefore, it can be concluded that the new model, $4+1$ dimension of value is acceptable.

\section{Indonesian Generation Z's Perceptions about Local Brands}

The questionnaire includes the question that refers to the customer's point of view towards local brands and comparing it to global brands. The results showed that the respondents, representing the whole Indonesian generation Z, still see the country of origin of a product but disagree towards the statement of how the respondents do not believe in local products and that local products are not able to compete with global brands.

Table 3: Country of Origin Results

\begin{tabular}{clcccc}
\hline \multirow{2}{*}{ Variables } & \multicolumn{1}{c}{ Statement } & \multicolumn{3}{c}{ Scale of Agreement } \\
\cline { 3 - 5 } COO1 & $\begin{array}{l}\text { "The brand's country of origin } \\
\text { (national identity) matters a lot for } \\
\text { me in purchasing a product" }\end{array}$ & $12,80 \%$ & $32.90 \%$ & $31.80 \%$ & $22.60 \%$ \\
\hline
\end{tabular}


Volume 3 Issue 9 (September 2021) PP. 36-46 DOI 10.35631/AIJBES.39004

\begin{tabular}{clllll}
\hline COO2 & $\begin{array}{l}\text { "I don't trust of want to buy } \\
\text { Indonesian local products" }\end{array}$ & $62.00 \%$ & $18.70 \%$ & $10.10 \%$ & $9.20 \%$ \\
\hline \multirow{2}{*}{ "Indonesian local products are } & $\begin{array}{l}\text { NOT able to compete with global } \\
\text { brands" }\end{array}$ & $44.50 \%$ & $25.20 \%$ & $16.60 \%$ & $13.60 \%$ \\
\hline
\end{tabular}

Seen from Table 3, the respondents answered mostly that they value country of origin or the national identity of a product when they are about to buy something. However, the COO2 and COO3, which invites the respondents' perspectives towards Indonesian local products, they answered mostly that they trust local products and they believe that Indonesia's local products are able to compete with global brands in the market. Therefore, it can be concluded that the label of "local products" or "made in Indonesia" will not have negative influence towards the customer's perceived values in a product.

\section{Conclusion}

From this research, it can be concluded that all of the 4+1 dimensions of value, functional, economic, emotional, social and service value dimension are significant towards the customer's willingness to pay higher price. Among all variables, value for money from economic dimension of value has the highest average scale and therefore sellers should enhance it more on their products. They are suggested to be confident, since the data shown that Indonesian generation $\mathrm{Z}$ are already open minded and willing to consume local products, and show their value more to the market. Show them why the business' products are worth to be exchanged for customers' money because these are what matter most to them. However, to increase value that linear with the prices set for the products, sellers or business owners may refer to the $4+1$ dimensions of value since they are all significant towards Indonesian generation Z's willingness to pay higher prices.

\section{References}

Asshidin, N. H. N., Abidin, N. and Borhan, H. B. (2016) 'Perceived Quality and Emotional Value that Influence Consumer's Purchase Intention towards American and Local Products', Procedia Economics and Finance, 35(October 2015), pp. 639-643. doi: 10.1016/s2212-5671(16)00078-2.

Budrevičiūte, A. et al. (2019) 'Perceptions of social, emotional, and functional values in patients with type 2 diabetes mellitus and their satisfaction with primary health care services', Primary health care research \& development, 20, p. e122. doi: 10.1017/S1463423619000471.

Dangmei, J. and Singh, A. P. (2016) 'Understanding the Generation Z: The Future Workforce', 3(3), pp. 1-5. Available at: http://library1.nida.ac.th/termpaper6/sd/2554/19755.pdf.

Demirgüneş, B. K. (2015) 'Relative Importance of Perceived Value, Satisfaction and Perceived Risk on Willingness to Pay More', 5(4), pp. 211-220.

Dolot, A. (2018) 'The characteristics of Generation Z', E-Mentor, (74), pp. 44-50. doi: $10.15219 / \mathrm{em} 74.1351$.

Jiao, Y. et al. (2018) 'Social value, content value, and brand equity in social media brand communities: A comparison of Chinese and US consumers', International Marketing Review, 35(1), pp. 18-41. doi: 10.1108/IMR-07-2016-0132.

Kussudyarsana, K. (2016) 'Persepsi Konsumen atas Merek Lokal dan Asing Pada Kategori Produk Hedonik dan Utilitarian', Benefit: Jurnal Manajemen dan Bisnis, 1(1), p. 48. doi: 10.23917/benefit.v1i1.2365. 
Volume 3 Issue 9 (September 2021) PP. 36-46 DOI 10.35631/AIJBES.39004

Lopes, A. B. and Galletta, D. F. (2006) 'Consumer Perceptions and Willingness to Pay for Intrinsically Motivated Online Content', Journal of Management Information Systems, 23(2), pp. 203-231. Available at: http://www.jstor.org/stable/40398847.

Netemeyer, R. et al. (2004) 'Developing and validating measures of facets of customer-based brand equity', Journal of Business Research, 57, pp. 209-224. doi: 10.1016/S01482963(01)00303-4.

Nguyen, T. N. et al. (2015) 'An Exploratory Investigation into Customer Perceived Value of Food Products in Vietnam', International Business Research, 8(12), p. 1. doi: 10.5539/ibr.v8n12p1.

Oblinger, D. G. and Oblinger, J. L. (2005) Educating the Net Generation.

Ratriyana, I. N. (2018) 'Global Brand Perception in Indonesian Young Consumer', KnE Social Sciences, 3(10), p. 357. doi: 10.18502/kss.v3i10.2921.

Sammut-bonnici (2017) 'Pricing Strategy', 12(October). doi: 10.1002/9781118785317.weom120162.

Sánchez-Fernández, R. and Iniesta-Bonillo, M. Á. (2009) 'Efficiency and quality as economic dimensions of perceived value: Conceptualization, measurement, and effect on satisfaction', Journal of Retailing and Consumer Services, 16(6), pp. 425-433. doi: 10.1016/j.jretconser.2009.06.003.

Schuiling, I. and Kapferer, J. N. (2004) 'Executive insights: Real differences between local and international brands: Strategic implications for international marketers', Journal of International Marketing, 12(4), pp. 97-112. doi: 10.1509/jimk.12.4.97.53217.

Selase, A. E. et al. (2018) 'The Identity of Brand with its Influenceable Character on Client Choices of Predominant Restaurants Accra as the Lens', Journal of Accounting \& Marketing, 07(04). doi: 10.4172/2168-9601.1000302.

Sulhaini, S., Rinuastuti, B. H. and Sakti, D. P. B. (2019) 'The halo effect of foreign brands on the misclassification of local brands', Management and Marketing, 14(4), pp. 357-371. doi: 10.2478/mmcks-2019-0025.

Sweeney, J. C. and Soutar, G. N. (2001) 'Consumer perceived value: The development of a multiple item scale', Journal of Retailing, 77(2), pp. 203-220. doi: 10.1016/S00224359(01)00041-0.

Weber, T. A. (2012) 'Price Theory in Economics', The Oxford Handbook of Pricing Management. doi: 10.1093/oxfordhb/9780199543175.013.0017.

Zahid, Z. (2017) 'Role of Image Value and Functional Value in Developing the Purchase Intentions and WOM Marketing', 9(7), pp. 46-55.

Zeithaml, V. A. (1988) 'Consumer Perceptions of Price, Quality, and Value: A Means-End Model and Synthesis of Evidence', Journal of Marketing, 52(3), pp. 2-22. doi: $10.1177 / 002224298805200302$.

Žemgulienè, J. (2014) 'Relative importance of retail store image and consumers characteristics on the perception of value and willingness to pay a premium price', Regional Formation and Development Studies, 9. doi: 10.15181/rfds.v9i1.602. 